\title{
Pengelolaan Perpustakaan Madrasah di Kota Palangka Raya (Studi terhadap Upaya Madrasah Menjadikan Perpustakaan Sebagai Sumber Belajar dan Bagian dari Sistem Pengajaran)
}

\author{
Usman, ${ }^{1 \star}$ Siti Narani ${ }^{2}$ \\ ${ }^{1,2}$ IAIN Palangka Raya \\ ^Email: usmansagassmhi@gamil.com
}

\begin{abstract}
The role of the madrasah library is not just infrastructure that must be available at the madrasah, but also must be managed properly according to standards and can truly function as a learning resource that can meet information for students and educators that ultimately can improve student competency and quality of the process of education and teaching in madrasah. Madrasah libraries in the city of Palangka Raya are still far from expectations, many libraries are managed only to meet the availability of infrastructure in madrasah. But there are still not many who manage the library properly to be used as a source of learning and part of the teaching system in the madrasah, therefore the purpose of this study is to find out how the efforts of the madrasah library make the library as a learning resource and part of the teaching system which includes development plans madrasah library, library staff development program, collection development and management activities, infrastructure development, service systems used and library programs in increasing the use of libraries in madrasah.

This research is a field research with a qualitative descriptive approach. The respondents in this study were madrasah library managers and there were 11 madrasah that were sampled from 35 madrasah in Palangka Raya City.

The results of this study are, madrasah efforts to make libraries as a source of learning and teaching system in madrasah from the aspect of planning, madrasah libraries do not have a strategic plan and grand design related to library development, madrasah libraries still get minimal budget for collection development and some even no, there are
\end{abstract}


still many library management personnel who are not yet professional, infrastructure facilities that are not yet standard, the service system is still manual and information technology has not been maximally applied. While the efforts made by the madrasah for the use of the library by teachers and students are the movement of reading $15 \mathrm{~min}$ utes before learning or during breaks in the library, distributing a collection of library books in every reading corner in the class, giving rewards to students who frequently visit the library, inviting students to visit Other libraries, film screenings in the library and holding collection display cabinets in the school grounds.

Keyword: $\quad$ Madrasah library, library management, field research, Madrasah libraries.

\begin{abstract}
Abstrak
Peran Perpustakaan Madrasah bukan hanya sekedar infrastruktur yang harus tersedia di Madrasah, tetapi juga harus dikelola dengan baik sesuai standar dan dapat berfungsi sebagai sumber daya pembelajaran yang dapat memenuhi informasi bagi siswa dan pendidik yang pada akhirnya dapat meningkatkan kompetensi siswa dan mutu proses pendidikan dan pengajaran di Madrasah. Perpustakaan Madrasah di kota Palangka Raya masih jauh dari ekspektasi, banyak perpustakaan yang dikelola hanya untuk memenuhi ketersediaan infrastruktur di Madrasah. Namun masih belum banyak yang mengelola perpustakaan dengan baik untuk dijadikan sumber pembelajaran dan bagian dari sistem pengajaran di Madrasah, oleh karena itu tujuan dari kajian ini adalah untuk mengetahui bagaimana upaya dari perpustakaan Madrasah menjadikan perpustakaan sebagai sumber pembelajaran dan bagian dari sistem pengajaran yang meliputi rencana pembangunan Madrasah Library, program pengembangan Staf Perpustakaan, pengembangan koleksi dan kegiatan manajemen, pengembangan infrastruktur, sistem pelayanan yang digunakan dan program Perpustakaan dalam meningkatkan penggunaan Perpustakaan di Madrasah.

Penelitian ini adalah penelitian lapangan dengan pendekatan deskriptif kualitatif. Para responden dalam kajian ini adalah pengurus Madrasah dan ada 11 Madrasah yang diteliti dari 35 Madrasah di kota Palangka Raya.

Hasil penelitian ini adalah, usaha Madrasah untuk membuat perpustakaan sebagai sumber pembelajaran dan sistem pengajaran Madrasah dari segi perencanaan, Madrasah perpustakaan tidak memiliki rencana strategis dan desain besar yang berkaitan dengan pengembangan Perpustakaan, Madrasah Perpustakaan masih mendapatkan anggaran minimal untuk pengembangan koleksi dan beberapa bahkan tidak ada, masih banyak personil Manajemen Perpustakaan yang belum profesional, sarana infrastruktur yang belum standar, sistem pelayanan masih
\end{abstract}


manual dan teknologi informasi belum diterapkan secara maksimal. Sementara usaha yang dilakukan oleh Madrasah untuk penggunaan Perpustakaan oleh guru dan siswa adalah gerakan membaca 15 menit sebelum belajar atau selama istirahat di Perpustakaan, mendistribusikan koleksi buku perpustakaan di setiap sudut baca di kelas, memberikan penghargaan kepada siswa yang sering mengunjungi Perpustakaan, mengundang siswa untuk mengunjungi perpustakaan lain, pemutaran film di Perpustakaan dan memegang lemari Display koleksi di Halaman sekolah.

Kata kunci: Perpustakaan Madrasah, Managemen Perpustakaan, Penelitian lapangan

\section{Pendahuluan}

Perpustakaan Madrasah sebagai salah satu sarana pendidikan penunjang kegiatan belajar siswa memegang peranan yang sangat penting dalam memacu tercapainya tujuan pendidikan di madrasah. Undang-undang Nomor 20 Tahun 2003 tentang Sistem Pendidikan Nasional pada Bab III Pasal 35 , menyatakan bahwa "Salah satu sumber belajar yang amat penting, tetapi bukan satu-satunya adalah perpustakaan yang memungkinkan para tenaga pendidik dan peserta didik memperoleh kesempatan untuk memperluas dan memperdalam ilmu pengetahuan dengan membaca bahan pustaka yang tersedia dengan mudah dan praktis sebagai bahan/materi pengetahuan dalam usaha proses belajar mengajar."

Dalam Undang-undang Perpustakaan No. 43 tahun 2007 pasal 23 disebutkan bahwa setiap sekolah/madrasah menyelenggarakan perpustakaan yang memenuhi standar nasional perpustakaan dengan memperhatikan standar nasional pendidikan, memiliki koleksi buku yang mencukupi untuk melayani semua peserta didik, mengembangkan koleksi perpustakaan yang mendukung kurikulum pendidikan, memberikan layanan terhadap semua peserta didik, berbasis teknologi informasi dan mengalokasikan dana paling sedikit 5\% dari anggaran belanja operasional sekolah/madrasah atau belanja barang di luar belanja pegawai dan belanja modal untuk pengembangan perpustakaan. $^{2}$

\footnotetext{
${ }^{1}$ Undang-Undang Nomor 20 Tahun 2003 tentang Sistem Pendidikan Nasional

${ }^{2}$ Undang-undang RI No. 43 Tahun 2017 tentang Perpustakaan
} 
Lebih lanjut pada pasal 43 dijelaskan bahwa penyelenggaraan perpustakaan madrasah menjadi tanggung jawab masing-masing sekolah/ madrasah dan dipimpin oleh seorang kepala. ${ }^{3}$

Perpustakaan sekolah/madrasah menurut Mbulu yang dikutif oleh Darmono bahwa keberadaannya diperlukan dengan pertimbangan bahwa perpustakaan sekolah/madrasah adalah sebagai sumber belajar di lingkungan sekolah, sebagai salah satu komponen sistem pengajaran, sebagai sumber untuk menunjang kualitas pendidikan dan pengajaran, sebagai laboratorium belajar yang memungkinkan peserta didik dapat mempertajam dan memperluas kemampuan untuk membaca, menulis, berpikir dan berkomunikasi. ${ }^{4}$ Adapun peranan sebuah perpustakaan madrasah menurut Pawit M.Yusuf adalah sebagai media dan sarana untuk menunjang kegiatan proses belajar mengajar di tingkat madrasah. Hal itu merupakan bagian integral dari program penyelenggaraan pendidikan tingkat madrasah. ${ }^{5}$ Sedangkan menurut Dian Sinaga perpustakaan memegang peranan penting dalam upaya memelihara dan meningkatkan efisiensi dan efektifitas proses belajar-mengajar. Perpustakaan yang terorganisir secara baik dan sistematis, secara langsung atau pun tidak langsung dapat memberikan kemudahan bagi proses belajar mengajar di sekolah/madrasah tempat perpustakaan tersebut berada. Hal ini terkait dengan kemajuan bidang pendidikan dan dengan adanya perbaikan metode belajar-mengajar yang dirasakan tidak bisa dipisahkan dari masalah penyediaan fasilitas dan sarana pendidikan. ${ }^{6}$

Dari uraian di atas dapat difahami bahwa perpustakaan madrasah peranannya tidak hanya sekedar sarana prasarana yang harus ada di madrasah namun juga perpustakaan harus dikelola secara baik sesuai standar serta benar-benar dapat difungsikan sebagai sumber belajar yang dapat memenuhi informasi bagi peserta didik dan tenaga pendidik yang pada akhirnya dapat

\footnotetext{
${ }^{3}$ Ibid

${ }^{4}$ Darmono, Manajemen dan tata kerja perpustakaan sekolah, Jakarta: PT. Grasindo, 2001, hal. 22

${ }^{5}$ Yusuf, Pawit M. dan Suhendar,Yaya.Pedoman Penyelenggaraan Perpustakaan Sekolah. Jakarta: Kencana, 2005. Hal. 2-4

${ }^{6}$ Dian Sinaga, Mengelola Perpustakaan Sekolah, (Jakarta: Kreasi Media Utama, 2007), hlm.15
} 
meningkatkan kompetensi siswa dan kwalitas dari proses pendidikan dan pengajaran di madrasah. Selain itu perpustakaan madrasah yang dikelola secara baik diharapkan dapat menumbuhkan kembangkan minat baca siswa yaitu dengan mengembangkan koleksi perpustakaan yang berkwalitas dan diminati oleh siswa.

Namun kenyataannya masih banyak perpustakaan madrasah yang belum maksimal dalam menjalankan perannya di madrasah. Perpustakaan madrasah masih banyak belum memenuhi standar pengelolaan yang telah diatur dalam undang-undang.

Perpustakaan Madrasah yang ada di kota Palangka Raya berdasarkan pengamatan penulis sementara kondisinya masih jauh dari harapan, banyak perpustakaan yang dikelola hanya untuk memenuhi ketersedian sarana prasarana di madrasah. Namun masih belum banyak yang mengelola perpustakaan untuk memenuhi standar pengelolaan perpustakaan di madrasah. Perkembangan koleksi di perpustakaan madrasah juga lambat, perpustakaan madrasah masih banyak menyimpan koleksi yang lama dan hampir tidak pernah lagi digunakan oleh siswa. sehingga perpustakaan madarasah hanya terlihat seperti tempat penyimpanan berkas-berkas saja. Sehingga hal ini juga menyebabkan perpustakaan madrasah masih belum dapat dijadikan sebagai bagian dari sistem pengajaran di madrasah. Upayaupaya yang dilakukan oleh madrasah untuk menjadiakan perpustakaan sebagai sumber belajar masih belum maksimal. Apresiasi kepala madrasah terhadap perpustakaan madrasah masih rendah. Kebijakan yang dibuat untuk pengembangan madrasah masih belum menyentuh aspek pengembangan perpustakaan. Perpustakaan madrasah di kota Palangka Raya masih banyak yang tidak mempunyai tenaga profesional untuk mengelola perpustakaan. Tenaga pengelola perpustakaan madrasah yang berlatar belakang perpustakaan belum bisa dimanfaatkan dan diberdayakan sesuai kompetensinya, namun dijadikan sebagai tenaga administrasi. Kegiatan pelatihan yang sering diikuti oleh pengelola perpustakaan madrasah juga sulit untuk diimplementasikan di perpustakaan madrasah. Begitu pula aplikasi sistem pengelolaan perpustakaan yang mudah didadapatkan masih 
sulit untuk diterapkandi perpustakaan madrasah.Oleh karena itu kami ingin mengetahui lebih lanjut dan mendalam terkait dengan masalah ini melalui sebuah penelitian.

Sehingga permasalahan yang kami angkat dalam penelitian ini adalah bagaimana upaya madrasah menjadikan perpustakaan sebagai sumber belajar dan bagian dari sistem pengajaran di madrasah di kota Palangka Raya meliputi aspek bagaimana rencana pengembangan perpustakaan di madrasah?Bagaimana program pengembangan tenaga perpustakaan di Madrasah? Bagaimana kegiatan pengembangan dan pengelolaan koleksi perpustakaan pada madrasah? Bagaimana peningkatan sarana prasarana perpustakaan di Madrasah? Bagaimana sistem layanan perpustakaan di madrasah? Bagaimana program pemanfaatan perpustakaan oleh guru dan siswa di madrasah?

Penelitian tentang pengelolaan perpustakaan madrasah di kota Palangka Raya dikaji dalam dua konsep keilmuan, yang pertama dari konsep manajemen perpustakaan dan kedua dari konsep perpustakaan sebagai sarana pembelajaran.

Konsep manajemen perpustakaan meliputi pengertian, kedudukan dan fungsi perpustakaan madrasah; manajemen pengelolaan koleksi, manajemen sarana prasarana dan manajemen layanan perpustakaan. Sedangkan dalam konsep perpustakaan sebagai sarana pembelajaran adalah terkait dengan perpustakaan sebagai sumber belajar dan perpustakaan sebagai sarana pembelajaran.

\section{Tinjauan Pustaka}

\section{a. Kedudukan dan Fungsi Perpustakaan Madrasah}

Perpustakaan sekolah/madrasah adalah perpustakaan yang merupakan bagian integral dari kegiatan pembelajaran dan berfungsi sebagai pusat sumber belajar untuk mendukung tercapainya tujuan pendidikan yang berkedudukan di sekolah. $^{7}$

\footnotetext{
${ }^{7}$ PP nomor 24 Tahun 2014 tentang Perpustakaan
} 
Menurut Darmono perpustakaan sekolah/madrasah adalah pusat sumber belajar dan sumber informasi bagi pemakainya. Perpustakaan madrasah sebagai tempat kumpulan buku-buku atau tempat buku dihimpun dan diorganisasikan sebagai media belajar siswa. ${ }^{8}$ Menurut Andi Prastowo perpustakaan sekolah/madrasah adalah sarana penunjang pendidikan di sekolah/madrasah yang berupa kumpulan bahan pustaka, baik berupa buku maupun non buku. Kumpulan bahan pustaka tersebut diorganisir secara sistematis dalam satu ruang sehingga dapat membantu siswa dan guru dalam proses pembelajaran. ${ }^{9}$

Undang-undang Nomor 20 Tahun 2003 tentang Sistem Pendidikan Nasional pada Bab III Pasal 35, bahwa "Salah satu sumber belajar yang amat penting, tetapi bukan satu-satunya adalah perpustakaan yang memungkinkan para tenaga pendidik dan peserta didik memperoleh kesempatan untuk memperluas dan memperdalam ilmu pengetahuan dengan membaca bahan pustaka yang tersedia dengan mudah dan praktis sebagai bahan/materi pengetahuan dalam usaha proses belajar mengajar."10

Selanjutnya undang-undang Nomor 20 Tahun 2003 tentang Sistem Pendidikan Nasional, pasal 45, meskipun tidak secara implisit menyebutkan agar setiap satuan pendidikan jalur pendidikan harus menyediakan perpustakaan sebagai sumber belajar. Akan tetapi, Undang-undang tersebut menyatakan bahwa "setiap satuan pendidikan formal dan nonformal menyediakan sarana dan prasarana yang memenuhi keperluan pendidikan sesuai dengan pertumbuhan dan perkembangan potensi fisik, kecerdasan intelektual, sosial, emosional, dan kejiwaan peserta didik. ${ }^{11}$

Selanjutnya lebih khusus diatur dalam Peraturan Menteri Pendidikan Nasional RI Nomor 24 tahun 2007 tentang standar sarana dan prasarana untuk sekolah dasar/madrasah ibtidaiyah (SD/MI), Sekolah Menengah hal. 1-2

${ }^{8}$ Darmono, Manajemen dan tata keraja perapustakaan sekolah, Jakarata: Grasindo, 2001,

${ }^{9}$ Andi Prastowo, Manajemen perpustakaan sekolah professional, Yogyakarta: Diva Press, 2012, hal. 45

${ }^{10}$ Undang-Undang Nomor 20 Tahun 2003tentang Sistem Pendidikan Nasional

${ }^{11}$ Undang-Undang Nomor 20 Tahun 2003tentang Sistem Pendidikan Nasional 
Pertama/Madrasah Tsaniwiyah (SMP/MTs), dan Sekolah Menengah Atas/ Madrasah Aliyah (SM/MA) menyebutkan perpustakaan salah satu dari sarana prasarana minimal yang harus dimiliki oleh tingkatan sekolah. ${ }^{12}$

Dengan demikian perpustakaan madrasah adalah termasuk sarana prasarana madrasah yang mesti disediakan oleh madrasah dan kedudukannya sama dengan sarana belajar yang lain di madrasah dan bahkan diatur sebagai bagian dari standar sarana prasarana di madrasah melalui Permendiknas nomor 24 tahun 2007 tentang standar sarana prasarana untuk sekolah/ madrasah.

Perpustakaan Madrasah berfungsi sebagai wahana pendidikan, penelitian, pelestarian, informasi dan rekreasi untuk meningkatkan kecerdasan dan keberdayaan bangsa. ${ }^{13}$

a. Fungsi Pendidikan; perpustakaan menyediakan informasi yang menunjang terlaksananya tujuan pendidikan di sekolah

b. Fungsi Penelitian; Perpustakaan menyediakan berbagai informasi untuk menunjang kegiatan penelitian

c. Fungsi Pelestarian atau deposit; Perpustakaan berkewajiban menyimpan dan melestarikan semua karya cetak dan karya rekam yang diterbitkan atau dibuat oleh madrasah.

d. Fungsi Informasi; Perpustakaan menyediakan berbagai informasi yang meliputi bahan tercetak, terekam maupun koleksi lainnya yang bersifat memberikan informasi bagi pemustaka

e. Fungsi Rekreasi; informasi maupun sarana yang disediakan perpustakaan dapat difungsikan sebagai sarana rekreasi bagi pengunjung perpustakaan.

\section{b. Pengelolaan Perpustakaan Madrasah}

Pengelolan perpustakaan madrasah di sini meliputi pengelolaan sumber daya manusia perpustakaan, sarana prasarana perpustakaan, pengelolaan koleksi perpustakaan, dan pengelolaan layanan perpustakaan

${ }^{12}$ Peraturan Menteri Pendidikan Nasional Nomor 25 Tahun 2008 tentang standar Tenaga Perpustakaan Sekolah/Madrasah

${ }^{13}$ Undang-undang RI No. 43 Tahun 2017 tentang Perpustakaan 
Setiap penyelenggara perpustakaan madrasah wajib berpedoman pada Standar Nasional Perpustakaan yang meliputi antara lain Standar Tenaga Perpustakaan (SDM), Standar Koleksi Perpustakaan, Standar Sarana dan Prasarana, Standar Pelayanan Perpustakaan dan juga Anggaran dengan memperhatikan kebutuhan pemustaka yang memiliki kelainan fisik, emosional, mental, intelektual dan/atau sosial.

Pengelolaan layanan perpustakaan diatur dalam standar layanan perpustakaan; standar ini memuat kriteria paling sedikit mengenai sistem dan jenis pelayanan. Sistem pelayanan perpustakaan terdiri dari sistem terbuka dan sistem tertutup yang ditentukan oleh setiap perpustakan madrasah. Jenis pelayanan perpustakaan terdiri dari pelayanan teknis dan pelayanan pemustaka. Pelayanan teknis mencakup pengadaan dan pengolahan bahan perpustakaan, sedangkan pelayanan pemustaka mencakup pelayanan sirkulasi dan pelayanan referensi. Waktu dan jumlah jam pelayanan perpustakaan disesuaikan dengan kebutuhan pemustaka dengan mempertimbangkan kemudahan pemustaka dalam menggunakan perpustakaan. ${ }^{14}$

\section{c. Faktor-faktor yangmempengaruhi Pengelolaan perpustakaan Madrasah}

Ada beberapa faktor yang dapat memepengaruhi pengelolaan perpustakaan madrasah, yaitu :

a. Minat Siswa

Faktor minat siswa sangat menentukan terhadap pemanfaatan perpustakaan madrasah, karena minat siswa merupakan kesadaran pribadi dari siswa yang mendorong jiwanya untuk memanfaatkan semua koleksi maupun sarana dan prasarana yang ada di perpustakaan demi kelancaran studinya. Seperti yang dikatakan Sardiman A.M. bahwa minat diartikan sebagai suatu kondisi yang terjadi apabila seseorang melihat cirriciri atau situasi yang dihubungkan dengan keinginan-keinginan atau kebutuhannya sendiri. ${ }^{15}$

\footnotetext{
${ }^{14}$ PP nomor 24 Tahun 2014 tentang Perpustakaan, hal 7-22

${ }^{15}$ Sardiman A.M.; Interaksi dan Motivasi Belajar Mengajar, Jakarta; Rajawali Pers, 2012
} 
b. Tenaga Pengelola (SDM)

Perpustakaan madrasah sebagai salah satu sumber belajar, harus dikelola oleh tenaga ahli yang benar-benar mempunyai kemampuan/kompetensi dalam pengelolaan perpustakaan madrasah.

c. Koleksi Perpustakaan

Koleksi perpustakaan madrasah menurut Andi Prastowo adalah sekumpulan bahan pustaka, baik yang berbentuk buku maupun nonbuku, yang dikelola sedemikian rupa oleh suatu perpustakaan (sekolah) untuk turut serta menjamin kelancaran dan keberhasilan kegiatanan proses pembelajaran di sekolah. ${ }^{16}$

Semua bahan pustaka yang dimiliki perpustakaan harus dapat menunjang proses belajar mengajar, karena itulah dalam pengadaan bahan pustaka harus mempertimbangkan kurikulum serta selera pemustaka yang sifatnya hiburan seperti novel dan buku cerita atau pengetahuan umum. Penambahan koleksi perpustakaan madrasah diadakan setiap tahun sehingga dapat memenuhi kebutuhan koleksi pemustaka dan kurikulum.

d. Sarana dan Prasarana

Sarana dan prasarana perpustakaan juga merupakan faktor yang penting sebagai penunjang faktor-faktor yang lainnya. Sarana dan prasarana di perpustakaan madrasah setidaknya paling sedikit meliputi tiga bentuk yaitu ruangan perpustakaan, perlengkapan perpustakaan dan peralatan perpustakaan.

\section{d. Perpustakaan Madrasah sebagai Sumber Belajar}

Perpustakaan sebagai sumber belajar maksudnya perpustakaan merupakan salah satu dari berbagai macam sumber-sumber belajar yang ada dilingkungan madrasah. Menurut Association for Education Communication Tecnology (AECT), yang dimaksud sumber belajar adalah berbagai sumber baik itu berupa data, orang atau wujud tertentu yang dapat digunakan oleh siswa dalam belajar baik yang digunakan secara terpisah maupun secara

${ }^{16}$ Andi Praswoto; Manajemen Perpustakaan Sekolah Profesional, Diva Press, 2012, hal. 116 
terkombinasi sehingga mempermudah siswa dalam mencapai tujuan belajarnya.

Ditinjau dari segi pendayagunaan, AECT membedakan sumber belajar menjadi dua macam yaitu

a. Sumber belajar yang dirancang atau sengaja dibuat untuk digunakan dalam kegiatan belajar untuk mencapai tujuan pembelajaran tertentu. Sumber belajar yang dirancang ini dapat berupa buku teks, buku paket, slide, film, video dan lain-lain yang memang dirancang untuk membantu mencapai tujuan pembelajaran tertentu.

b. Sumber belajar yang tidak dirancang atau tidak sengaja dibuat untuk membantu mencapai tujuan pembelajaran. Jenis ini banyak terdapat di sekitar kita dan jika suatu saat kita membutuhkan, maka tinggal memanfaatkannya, misalnya toko, pasar, museum dan lain-lain.

Berdasarkan pada definisi di atas, maka sumber belajar jenis pertama yaitu sumber belajar yang sengaja dibuat untuk membantu pencapaian tujuan belajar perlu disimpan di perpustakaan untuk dapat didayagunakan secara maksimal dan berulang-ulang. Karena itulah maka perpustakaan merupakan salah satu sarana yang dibutuhkan di lingkungan madrasah sehingga dapat membantu tercapainya setiap upaya pembelajaran. ${ }^{17}$

Sumantri menjelaskan perpustakaan sekolah sebagai sumber belajar yang sangat penting mempunyai fungsi sebagai berikut: 1) Perpustakaan sekolah dapat berfungsi sebagai sumber informasi untuk memperjelas dan memperluas pengetahuan teknologi dan penunjang pembelajaran serta tempat mengadakan penelitia sederhana bagi peserta didik dan guru. 2) Bagi guru, perpustakaan sekolah merupakan tempat mencari sumber informasi pengetahuan dan rujukan bagi kepentingannya dalam mengajar. 3) Tempat pengembangan minat membaca akan pengetahuan bagi peserta didik secara mandiri. ${ }^{18}$ hal. 5-6

${ }^{17}$ Darmono, Manajemen dan Tata Kerja Perpustakaan Sekolah, Jakarata: Grasindo, 2001,

${ }^{18}$ Sumantri, MT. Panduan Penyelenggaraan Perpustakaan Sekolah. Bandung: PT Remaja Rosdakarya, 2008, hal. 3 


\section{e. Perpustakaan madrasah dan sistem pengajaran}

Pengajaran sebagai suatu sistem merupakan suatu pendekatan mengajar yang menekankan hubungan sistematik antara berbagai komponen dalam pengajaran. Hubungan sistematik ini mempunyai arti bahwa komponen yang terpadu dalam suatu pengajaran sesuai dengan fungsinya saling berhubungan satu sama lain dan membentuk suatu kesatuan. Dilihat dari konsep pendakatan sistem, bahwa bahan ajar berkaitan dengan kurikulum, kegiatan belajar mengajar, teknik dan metode pengajaran, kenyamanan dan suasana pembelajaran, sarana dan prasarana belajar yang layak dan mendukung berlangsungnya pembelajaran dengan baik dan menyenangkan. ${ }^{19}$

Dengan demikian bahwa perpustakaan sekolah/madrasah merupakan salah satu bagian dari komponen sarana prasarana dalam sistem pengajaran. Sehingga keberadaannya dibutuhkan dalam melaksanakan sistem pengajaran di sekolah/madrasah.

Mbulu menjelaskan bahwa perpustakaan sekolah dibutuhkan keberadaannya melalui pertimbangan bahwa : 1) Perpustakaan sekolah merupakan salah satu komponen sistem pengajaran. 2) Perpustakaan sekolah merupakan sumber belajar di lingkungan sekolah. 3) Perpustakaan sekolah merupakan sumber untuk menunjang kwalitas pendidikan dan pengajaran. 4) Perpustakaan sekolah sebagai laboratorium belajar yang memungkinkan peserta didik dapat mempertajam dan memperluas kemampuan untuk membaca, menulis, berpikir dan berkomunikasi. ${ }^{20}$

\section{Metode}

Penelitian ini merupakan penelitian lapangan (field research) yaitu penelitian yang obyeknya langsung berasal dari lapangan yang berupa data,

${ }^{19}$ Syaiful Sagala, Konsep dan makna pembelajaran: untuk membantu memecahkan problematika belajar dan mengajar, Bandung: Alfabeta, 2017, hal. 153-154

$20 \quad$ Mbulu, Joseph. Pemanfaatan Perpustakaan Sekolah Dalam Kegiatan Belajar Mengajar. Majalah Pendidikan, XIX. (1992).h.17 
baik yang didapat melalui wawancara langsung maupun dengan dokumentasi sebagai penunjang data. Adapun bentuk pendekatan penelitian ini adalah deskriptif kualitatif. Pendekatan deskriptif kualitatif dalam penelitian ini dimaksudkan untuk mengetahui dan memberikan gambaran tentang pengelolaan perpustakaan Madrasah kota Palangka Raya dalam hal usaha madrasah dalam menjadikan perpustakaan sebagai sumber belajar bagi peserta didik serta menjadikan perpustakaan sebagai bagian dari sistem pengajaran di madrasah.

Sampel dalam penelitian ini adalah berjumlah 3MIN 1 MIS, 2 MTsN, 2 MTsS, 1 MAN, 2 MAS. Sehingga ada 11 Madrasah yang dijadikan sampel dari seluruh populasi madrasah di Palangka Raya yang berjumlah 35 Madrasah.

Adapun untuk mengumpulan data penulis mempergunakan metode:Wawancara; Observasi; Survey; Focus Group Discussion (FGD); dan Dokumentasi. ${ }^{21}$

Selanjutnya data dianalisis kualitatif secara induksi dan deduksi. Sehingga data-data yang terkumpul dilakukan reduksi data yaitu dengan melakukan proses pemilihan terus menerus selama penelitian berlangsung dan membuang data-data yang tidak perlu, kemudian menggolongkannya ke dalam pola yang lebih luas. Selanjutnya data disajikan dalam bentuk teks naratif dan matriks, grafik, jaringan dan bagan, kemudian akhirnya penarikan kesimpulan yang juga terus diverifikasi selama penelitian berlangsung.

\section{Hasil dan Pembahasan}

Upaya Madrasah menjadikan perpustakaan sebagai sumber belajar dan sistem pengajaran di madrasah

Berbagai upaya yang dilakukan madrasah untuk menjadikan perpustakaan sebagai sumber belajar dan sistem pengajaran adalah meliputi aspek upaya madrasah membuat rencana pengembangan perpustakaan madrasah, peningkatan sumber daya pengelola perpustakaan di madrasah,

${ }^{21}$ Yati Afianti, Focus Group Discussion (diskusi kelompok terfokus) sebagai metode pengumpulan data penelitian kualitatif, Jurnal Keperawatan Indonesia, Volume 12, No. 1, Maret 2008; hal 59 
pengembangan koleksi dan pengelolaan koleksi di madrasah, peningkatan sarana prasarana perpustakaan madrasah meliputi perabot dan peralatan di perpustakaan madrasah, sistem layanan yang dijalankan di perpustakaan madrasah serta bentuk kegiatan dalam pemanfaatan perpustakaan oleh guru dan siswa di madrasah.

\section{Rencana Pengembangan Perpustakaan Madrasah}

Berdasarkan hasil wawancara dan observasi dari 11 perpustakaan madrasah di kota palangka Raya, semuanya punya program kerja yang menjadi pedoman mereka dalam mengelola perpustakaan, namun tidak satupun madrasah yang mempunyai rencana strategis atau grand desain untuk pengembangan perpustakaan madrasah. Program kerja yang mereka miliki ada yang tertulis di dokumen dan ada juga yang tertulis di dinding. Program kerja tersebut lebih banyak dibuat oleh pengelola sebelumnya dan hanya digunakan sebagai syarat dari sebuah organisasi perpustakaan. Program kerja yang dimaksud hanya berfungsi sebagai bagian dari job deskripsion pengelola perpustakaan, bukan yang dibuat disertai dengan rancangan anggaran kegiatan pertahun.Jadi program kerja yang mereka milikidapat digunakan sepanjang tahun. Jika dilakukan perubahan, maka bukan isinya tapi tahunnya saja. Seperti yang diungkapkan oleh ibu Sri Mustik bahwa, "program yang kami miliki ini sudah lama dan merupakan program yang dibikin oleh pengelola terdahulu". ${ }^{2}$

Adapun usulan perpustakaan terkait dengan pengadaan koleksi dan sarana prasarana lainnya lebih banyak didasarkan pada program yang dibuat oleh madrasah. Jika madrasah tidak memprogramkan terkait peningkatan sarana prasarna perpustakaan, maka pada tahun itu tidak ada pengadaan sarana prasarana bagi perpustakan. Dengan kata lain program yang dibuat untuk perpustakaan lebih bersifat dari atas ke bawah (Top-Down). Sehingga pengembangan perpustakaan setiap tahun tergantung pada pejabat yang berwenang dalam menyusun anggaran madrasah.

${ }^{22}$ Wawancara dengan ibu Sri Mustika dari pegelola perpustakan madrasah MIN 2hari Sabtu Agustus 2019 tanggal 27 Juli 2019 
Adapun terkait dengan sumber dana utama pengelolaan perpustakaan ada 2 jenis yaitu dari dana BOS dan dana Komite. Sebagian kecil ada juga yang berasal dari siswa seperti denda terlambat, cetak kartu anggota/KTS atau sumbangan lain yang tidak mengikat.

Meskipun demikian sumber pendanaan itu tidak selalu diberikan tiap tahunnya untuk perpustakaan, jika adajumlahnya sangat kecil dan bahkan hanya untuk keperluan ATK saja. Seperti yang disampaikan oleh Ibu Mustika dari MIN 2 Palangka Raya, "untuk 3 tahun belakangan ini kami perpustakaan hanya mendapatkan anggaran untuk ATK saja sedangkan koleksi dan sarana prasarana belum ada"23

Anggaran untuk pengadaan koleksi maupun sarana prasarana hampir semua perpustakaan madrasah tidak menerima langsung dalam bentuk uang namun mereka hanya menerima dalam bentuk barang seperti buku dan sarana prasarana lainnya berdasarkan usulan dari perpustakaan jika disetujui. Ada 2 perpustakaan madrasah yang mereka mengaku pernah dikasih dalam bentuk uang untuk belanja koleksi buku perpustakaan yang bersumber dari dana komite. Yaitu perpustakaan MTsN 1 dan MIN 1. Seperti yang diungkapkan oleh pengelola perpustakaan MTsN 1, "saya sebagai pengelola perpustakaan pernah dikasih sejumlah uang oleh kepala madrasah melalui bendahara untuk membeli sejumlah buku khususnya buku-buku cerita untuk anak-anak yang terlebih dahulu kami pilih melalui katalog yang diberikan oleh penerbit, kemudian hasil pembelian dalam bentuk daftar kami laporkan kepada kepala madrasah".

Anggaran untuk perpustakaan madrasah ini sebenarnya sudah diatur dalam undang-undang perpustakaan Nomor 43 tahun 2007 khususnya Pasal 23 ayat 6 menyatakan bahwa sekolah/madrasah mengalokasikan dana paling sedikit $5 \%$ dari anggaran belanja operasional sekolah/madrasah atau belanja barang di luar belanja pegawai dan belanja modal untuk pengembangan perpustakaan. Pedoman Perpustakaan Sekolah yang diadopsi oleh Perpustakaan Nasional RI dari Ikatan Perpustakaan Internasional [IFLA]

${ }^{23}$ Ibid 
juga menyebutkan bahwa anggaran material perpustakaan sekolah paling sedikit adalah 5\% untuk biaya per murid dalam sistim persekolahan, tidak termasuk untuk belanja gaji dan upah, pengeluaran pendidikan khusus, anggaran transportasi serta perbaikan gedung dan sarana lain.

Memperhatikan aturan di atas dan benar-benar dapat diterapkan pada madrasah semestinya perpustakaan madrasah setiap tahun akan selalu berkembang baik dari aspek koleksinya maupun sarana prasarananya.

Masih banyak madrasah yang beranggapan bahwa yang penting perpustakaan itu ada, ruangannya ada, raknya ada, dan pengelolanya ada. Keberadaan perpustakaan dianggap hanya sebagai pelengkap dari sarana sumber belajar di madrasah.

Pengelola perpustakaan madrasah idealnya memahami terkait dengan unsur-unsur anggaran perpustakaan madrasah dan juga memahami proses penganggaran yang berlangsung di madrasah, siapa yang berperan pening dalam penganggaran, kapan terkait dengan kjadwal siklus penggaran dan memastikan bahwa angaran untuk keperluan perpustakaan teridentifikasi oleh madrasah.

\section{Program pengembangan tenaga pengelola perpustakaan Madrasah}

Tenaga pengelola perpustakaan madrasah di kota Palangka Raya yang berlatar belakang pendidikan ilmu perpustakaan masih kurang, dari 11 madrasah yang di teliti hanya 2 madrasah yang mempunyai tenaga yang berlatar belakang pendidikan ilmu perpustakaan (D3) dan hanya berstatus tenaga honor. Tidak ada yang berstatus sebagai pegawai negeri.

Pengelola perpustakaan madrasah dari setiap madrasah yang diteliti rata-rata lebih dari 1 orang dan yang paling banyak adalah di MTsN 2 Palangka raya sebanyak 4 orang, sedangkan madrasah yang jumlah pengelola perpustakaannya 1 orang yaitu pada madrasah yang memang masih belum memiliki ruangan perpustakaan seperti di MA Hidayatul Insan dan MIN 3. Artinya dari aspekjumlah minimal pengelola perpustakaan, maka kebanyakan madrasah telah memenuhi standar tenaga pengelola perpustakaan sekolah/ madrasah seperti yang tercantum dalam dalam permendiknas nomor 25 
tahun 2008. Sedangkan terkait dengan latar belakang pendidikan pengelola perpustakaan, maka yang berlatar belakang pendidikan perpustakaan hanya berjumlah 2 orang dari 11 madrasah yang diteliti. Namun dari 2 orang itu bukan pegawai negeri sipil di madrasah tetapi statusnya honorer. Sedangkan untuk pengelola perpustakaan yang pernah mengikuti diklat selama lebih dari 100 jam ada 3 orang dan kebetulan semuanya berstatus koordinator perpustakaan atau kepala perpustakaan madrasah yang profesinya guru yang ditugaskan di perpustakaan dan masing-masing berasal dari MTsN 1, MTsN 2 dan MTs Muslimat NU. Diklat yang mereka ikuti dengan biaya sendiri 2 orang dan undangan dari balai diklat di Banjarbaru 1 orang (MTsN 2). Namun dari 3 koordinator perpustakaan madrasah ini tidak ada satupun yang memiliki sertifikat kompetensi sebagaimana yang diatur dalam permendiknas nomor 25 tahun 2008 tentang standar tenaga pengelola perpustakaan.

Adapun terkait dengan data pengelola perpustakaan yang berlatar belakang pendidikan ilmu perpustakaan dan berstatus pegawai negeri untuk seluruh madrasah di kota Palangka Raya belum ada, meskipun dari informasi yang kami dapatkan bahwa sebelumnya pernah perpustakaan MTsN 1 memiliki tenaga yang berlatar belakang pendidikan D3 ilmu perpustakaan yang direkrut melalui formasi pustakawan di madrasah, namun karena madrasah masih membutuhkan tenaga administrasi maka pegawai tersebut pada akhirnya hanya sebagai tenaga administrasi hingga mutasi ke MAN 1 Palangka Raya. Pada saat di MAN 1 ternyata juga tidak bisa diangkat sebagai pustakawan di sekolah, sehingga masih tetap sebagai tenaga administrasi di MAN 1 kemudian mutase lagi ke IAIN Palangka Raya. ${ }^{24}$

Menurut kepala madrasah Aliyah Negeri 1 yang kami temuai, bahwa dia tidak mengetahui waktu itu yang bersangkutan adalah berlatar belakang pendidikan perpustakaan dan punya keinginan sebagai pustakawan sehingga ketika pindah ke IAIN maka kami bersedia melepas. Padahal saat ini kami butuh tenaga perpustakaan yang profesional, selain itu kepala madrasah yang kami wawancari mengeluhkan bahwa perpustakaan madrasah kurang maju

${ }^{24}$ Wawancara dengan kepala perpustakaan MTsN 1 Palangka Raya tanggal 23 Juli 2019 
adalah disebabkan oleh kondisi tenaga pengelola yang tidak profesioanal dan inovatif. ${ }^{25}$

Madrasah tidak mempunyai program untuk peningkatan kompetensi SDM pengelola perpustakaan, termasuk kemenang kota Palangka Raya. Alasannya adalah sedikitnya anggaran yang disediakan dalam pengembangan madrasah. Sehingga kegiatan diklat maupun bimtek yang bisa diikuti oleh pengelola perpustakaan madrasah hanya didasarkan pada adanya undangan dari eksternal madrasah yang melakukan kegiatan. Biaya yang dikeluarkan untuk mengikuti diklat juga bersifat mandiri. Oleh karena itu kepala madrasah sangat senang sekali jika staf dari pengelola perpustakaannya diikutkan dalam kegiatan pelatihan yang dilaksanakan oleh instansi lain. Begitu pula bagi madrasah jika ada kegiatan di luar lembaga yang menfasilitasi dalam peningkatan kompetensi pengelola perpustakaan akan disambut dengan baik dan sangat mendukung.

Program pengembangan SDM dalam bentuk pelatihan maupun bimbingan teknis ini sebenarnya penting untuk mendukung peningkatan kompetensi para tenaga perpustakaan madrasah dalam melaksanakan tugasnya di perpustakaan madrasah dan bahkan dapat pula membantu program madrasah dalam upaya meningkatkan nilai akreditasi madrasah.

Meskipun demikian latar belakang pendidikan dan pelatihan yang telah diikuti oleh pengelola perpustakaan ternyata bukanlah hal yang utama yang menyebabkan kurang maksimalnya pengelolaan perpustakaan, tetapi lebih banyak disebabkan oleh komitmen dari pengelola perpustakaan yang beralasan bahwa sedikitnya waktu yang tersedia untuk mengelola perpustakaan berdasarkan ilmu yang sudah diberikan pada saat pelatihan. Terlebih lagi pengelola perpustakaan yang berlatar belakang guru lebih banyak tersita waktunya untuk mengajar.

Peranan pengelola perpustakaan sebenarnya adalah sebagai mediator antara informasi dengan pengguna, ${ }^{26}$ sehingga karena peranannya tersebut

${ }^{25}$ Wawancara dengan kepala Madrasah Aliyah Negeri Palangka Raya tanggal 22 Juli 2019

${ }^{26}$ Wolfe, J.,Naylor, T., \& Drueke, J. (2010). The Role of the Academic Reference Librarian in theLearning Commons. Reference \&User Services Quarterly, 50(2), 108-113 
maka pengelola perpustakaan madrasah dituntut untuk memiliki keahlian yang professional terkait dengan perpustakaan. Pengelola perpustakaan madrasah harus banyak memiliki pengetahuan terkait dengan sumber informasi, memiliki keahlian menganalisis, intelejensi emosional, dan kemampuan mengajar sehingga dapat membantu siswa dan guru dalam mendapatkan informasi yang dibutuhkan dan dapat meningkatkan minat baca bagi guru dan siswa.

Evans dan Carter menyebutkan bahwa perpustakaan menyediakan dua layanan. Yang pertama adalah menyediakan akses pada informasi dan yang kedua adalah menyediakan pustakawan yang ahli yang siap membantu pengguna untuk mengidentifikasi informasi yang dibutuhkan ${ }^{27}$. Dengan demikian peningkatan kompetensi pustakawan adalah termasuk salah satu komponen penting dalam program layanan perpustakaan.

\section{Pengembangan dan pengelolaan koleksi perpustakaan madrasah}

Koleksi pada sebuah perpustakaan memegang peranan yang sangat penting, karena produk utama yang ditawarkan oleh perpustakaan. Koleksi harus disesuaikan dengan kebutuhan pemustakanya dalam hal ini guru dan siswa. Salah satu aspek penting membuat perpustakaan dapat diminati oleh siswa adalah ketersediaan koleksi yang memadai dan memenuhi kebutuhan siswa, baik itu untuk mencari referensi tugas maupun hanya sekedar rekreasi dengan bacaan fiksi.

a. Pengembangan koleksi

Pengembangan koleksi perpustakaan adalah mencakup semua kegiatan untuk menambah atau memperluas koleksi yang ada di perpustakaan, terutama untuk kegiatan yang berkaitan dengan pemilihan dan evaluasi bahan pustaka. Kegiatan ini meliputi berbagai aktivitas seperti penyusunan kebijaksanaan, penetapan prosedur seleksi, pengadaan koleksi, serta evaluasi.

${ }^{27}$ Evans, G.E., \& Carter, T.L. (2009). Introduction to library public services ( $7^{\text {th }}$ ed.). Westport, Conn.: Libraries Unlimited, hal. 23 
Pengembangan koleksi di perpustakaan madrasah di kota Palangka Raya berdasarkan hasil wawancara yang peneliti lakukan dikatakan bahwa: "hampir setiap tahun untuk pengadaan koleksi ada, namun hanya koleksi buku pelajaran dan dilaksanakan secara terpusat atau tidak dilakukan sendiri oleh perpustakaan madrasah". ${ }^{28}$

Kebijakan pengadaan koleksi seperti ini umumnya sama pada setiap madrasah lainnya. Mereka hanya menerima buku datang, sehingga dapat dikatakan bahwa pengembangan koleksi di perpustakaan madrasah tidak banyak melibatkan perpustakaan dalam perencanaannya dan bahkan dalam prosesnya, khususnya terkait dengan koleksi buku pelajaran.

Pengadaan koleksi di perpustakaan madrasah umumnya ada 2 cara yaitu secara pembelian dan hadiah.

Pengadaan koleksi yang terkait dengan buku mata pelajaran anggarannya melalui dana BOS yang langsung dikoordinir oleh kemenag kota, sehingga madrasah hanya menerima buku datang. Sedangkan bukubuku yang terkait dengan pengayaan seperi buku cerita, referen dan lain-lain pengadaannya dilakukan sendiri oleh madrasah dengan dana yang bersumber dari sumbangan komite.

Pengadaan koleksi dengan sistem pembelian yang dilakukan sendiri oleh madrasah seperti dari dana komite ada 2 cara, pertama, pengelola perpustakaan disuruh pilih judul buku yang diperlukan kemudian dibelikan oleh madrasah, yang kedua pengelola perpustakaan diberikan sejumlah dana kemudian disuruh belanja sendiri kemudian hasilnya dilaporkan kepada kepala madrasah. Sumber dana dari komite untuk pembelian buku ini tidak setiap tahun ada, hanya ada 2 madrasah yang pengelola perpustakannya pernah dipercayakan belanja sendiri terkait dengan buku perpustakaan.

Adapun pengadaan dengan cara hadiah adalah perpustakaan madrasah membuat program menyumbangkan buku ke perpustakaan bagi siswa yang telah lulus atau siswa yang baru masuk ke madrasah. Jenis buku yang disumbangkan adalah yang bersifat buku bacaan dan bukan

\footnotetext{
${ }^{28}$ Wawancara dengan kooedinator pengelola perpustakaan MTsN 2 tanggal 23 Juli 2019
} 
buku pelajaran. Buku-buku yang jenisnya pengayaan ini memang masih sulit diadakan melalui anggaran madrasah, oleh karena lebih dioptimalkan pengadaannya melalui hadiah.

Perpustakaan madrasah yang diteliti semuanya belum memiliki kebijakan tertulis terkait dengan pengembangan koleksi. Sehingga bukubuku yang masuk masih belum terseleksi secara baik dan tidak ada kebijakan melakukan penolakan terhadap koleksi yang tidak sesuai atau tidak dibutuhkan oleh pengguna perpustakaan.

Perpustakaan madrasah juga merasa kesulitan ketika banyaknya buku-buku lama yang sudah tidak terpakai lagi khususnya buku-buku pelajaran. Kegiatan penyiangan (weeding) tidak pernah dilakukan. Sehingga rak perpustakaan lebih banyak dengan buku-buku pelajaran yang sebenarnya tidak lagi digunakan oleh siswa atau guru. Sebagaimana yang dinyatakan oleh salah seorang responden, "sebenarnya kami ingin memindahkan atau menyingkirkan buku-buku yang sudah tidak terpakai, tapi kami tidak mengetahui bagaimana prosedurnya, terutama buk-buku lama'.29

Berdasarkan pengamatan terhadap data dan keberadaan koleksi di rak yang dilakukan oleh tim peneliti pada umumnya perpustakaan madrasah sudah memenuhi standar koleksi perpustakaan sekolah/madrasah dari aspek kwantitas. Namun dari aspek jenis koleksi kebanyakan belum standar. Data koleksi yang diberikan oleh semua madrasah cenderung tidak akurat disebabkan belum maksimalnya dalam inventarisasi buku menurut standar pengelolaan koleksi di perpustakaan. Seperti madrasah Ibtidaiyah Negeri 2 yang tim peneliti observasi, menginventarisasi buku berdasarkan jenis dari subjek buku, seperti buku dengan subjek bahasa, 1 daftar, buku dengan subjek agama, 1 daftar dan seterusnya, sehingga banyak sekali daftar buku yang mereka miliki sesuai klasifikasi yng mereka buat. Sedangkan pada perpustakaan Madrasah Ibtidaiyah Negeri 1 hanya memiliki daftar buku yang dalam bentuk excel pertahun dengan menambahkan jumlah eksamplar pada setiap judul, tidak ada pemisahan menurut jenis koleksi dan memungkinkan

${ }^{29}$ Wawancara dengan pengelola perpustakaan MTsN 2 Kota Palangka Raya palangka raya tanggal 23 Juli 2019 
judulnya bertambah meskipun judul yang masuk sekarang sudah pernah masuk pada tahun sebelumnya dan eksamplarnya tidak bisa dijumlahkan, karena setiap judul yang sama mendapatkan nomor induk yang sama.

Selain koleksi dalam bentuk buku sebagian besar perpustakaan madrasah kecuali yang tidak memiliki ruangan perpustakaan, perpustakaan madrasah juga memiliki sejumlah koleksi sumber belajar lain yang mereka simpan di perpustakaan seperti majalah, surat kabar, globe, peta, gambar pahlawan dan alat peraga. Untuk majalah dan surat kabar tidak dilanggan langsung oleh perpustakaan tetapi oleh madrasah, sedangkan majalah adalah hadiah dari kemenag provinsi.

b. Pengelolaan koleksi

Koleksi yang datang ke perpustakaan biasanya dilakukan pengolahan agar bisa dilayankan kepada pemakai. Seluruh madrasah di kota Palangka Raya yang diteliti masih belum standar dalam pengelolaan, seperti tidak adanya buku induk untuk koleksi buku yang standar, sehingga menyebabkan tidak adanya nomor induk buku untuk seluruh koleksi, klasifikasi yang digunakan masih belum konsisten, tidak terdapatnya sarana temu balik informasi di perpustakaan seperti katalog, tidak adanya sarana yang standar untuk pengelohan koleksi seperti buku kalasifikasi DDC atau eDDC, buku tajuk subjek, dan lain-lain.

Perpustakaan madrasah yang diteliti hampir semuanya mengaku memiliki buku induk, ada yang dalam bentuk manual di buku besar ada yang diketik di komputer dalam bentuk word atau excel dan ada juga yang termuat dalam aplikasi, hanya ada 2 madrasah yang menyatakan tidak punya yang disebabkan oleh pengelola baru dan belum memiliki ruang perpustakaan. Namun dari seluruh perpustakaan madrasah yang diteliti dalam memberikan nomor induk untuk koleksi perpustakaan semuanya tidak standar, sehingga informasi yang mereka berikan terkait dengan jumlah koleksi baik judul maupun eksamplar datanya tidak valid. Jenis informasi yang semestinya mereka masukkan dalam buku induk masih kurang sehingga menyebabkan informasi koleksi menjadi ganda atau tidak diketahui jumlah eksamplarnya berdasarkan subjek buku. 
Padahal dengan membuat buku induk atau inventaris yang baik serta pengisian data yang tepat maka perpustakaan akan mudah dalam membuat statistik dan laporan tentang beberapa hal yaitu :

1) jumlah bahan pustaka yg dimiliki perpustakaan,

2) jumlah judul dan eksemplarnya,

3) jumlah judul dan eksemplarnya berdasarkan bahasa,

4) jumlah buku fiksi, buku teks, buku referensi, dan lain-lain,

5) jumlah penambahan bahan pustaka setiap tahun, dan

6) jumlah anggaran yang dikeluarkan. ${ }^{30}$

Ada juga perpustakaan madrasah yang kebijakannya hanya mengolah koleksi yang bukan buku pelajaran, seperti yang diungkapkan oleh pengelola perpustakaan MAN 1 Palangka Raya sebagai berikut:"koleksi buku yang kami kelola dan kami berikan barkot adalah buku yang bukan buku paket, karena buku paket itu terlalu banyak dan umumnya bila sudah beberapa tahun kemudian tidak terpakai lagi”. ${ }^{31}$

Ada 4 perpustakaan yang menyatakan bahwa dalam pengelolaan koleksi memakai aplikasi.

Tabel di atas menunjukkan bahwa dari 11 perpustakaan madrasah yang diteliti ada 4 perpustakaan madrasah yang mengaku menggunakan aplikasi untuk mengolah buku dan layanan pemakai. Ada 3 perpustakaan madrasah yang mengaku punya aplikasi namun belum bisa diterapkan dan ada 4 perpustakaan madrasah yang sama sekali tidak mempunyai aplikasi untuk pengelolaan perpustakaan.

c. Peningkatan sarana prasarana perpustakaan madrasah

Peningkatan sarana prasarana perpustakaan adalah juga bagian terpenting dalam menjadikan perpustakaan sebagai sumber belajar. Peningkatan sarana prasarana ini juga akan memotivasi siswa dan guru dalam memanfaatkan perpustakaan sebagai sumber belajar. Seperti menjadikan ruangan

${ }^{30}$ Qalyubi, Syihabuddin dkk. 2007. Dasar-Dasar Ilmu Perpustakaan dan Informasi. Yogyakarta: Jurusan Ilmu Perpustakaan dan Informasi (IPI) Fakultas Adab UIN Sunan Kalijaga. Hal 13

${ }^{31}$ Wawancara dengan Ibu pengelola perpustakaan Madrasah Aliyah Negeri 1 Palangka Raya tanggal 22 Juli 2019 
perpustakaan yang luas dan nyaman, serta perabot dan peralatan perpustakaan yang lengkap. Namun dari 11 madrasah yang kami kunjungi ternyata masih ada 2 madrasah yang belum memiliki ruangan perpustakaan sendiri, dan 2 madrasah ruang perpustakaannya bersama dengan ruangan lain.

Kondisi ruang perpustakaan madrasah di palangka Raya, pada umumnya telah memenuhi standar permendiknas nomor 24 tahun 2007, namun jika berdasarkan standar nasional perpustakaan sekolah/madrasah, maka hanya ada 1 perpustakaan yang luasnya sudah melebihi standar nasional perpustakaan sekolah/madrasah yang luasnya 72M2, yaitu perpustakaan MAN Kota Palangka Raya.

Berdasarkan hasil wawancara dengan pengelola perpustakaan madrasah dalam hal peningkatan sarana prasarana perpustakaan madrasah, semuanya menyatakan tidak mendapatkannya setiap tahun, bahkan ada yang ruang perpustakaan sementara ditiadakan untuk diganti dengan ruang laboratorium komputer untuk siswa ujian akhir, ada juga yang komputernya dialihkan untuk melengkapi jumlah komputer di laboratorium untuk siswa ujian. Sarana prasarana perpustakaan diperhatikan ketika ada momen akreditasi madrasah atau mengikuti lomba.

Perabot perpustakaan yang dimiliki oleh perpustakaan madrasah untuk rak secara jumlah cukup memenuhi standar yang digunakan untuk menampung koleksi perpustakaan Madrasah. Sedangkan meja baca, hanya ada 2 madrasah yang cukup banyak dan dikatakan memenuhi standar yaitu MAN 1 dan MTsN 2. Lemari katalog yang memiliki hanya MTsN 1, namun tidak ada juga kartu katalognya. Adapun Komputer tidak selalu milik perpustakaan namun yang mereka sebutkan termasuk juga laptop pribadi yang pengelola perpustakaan miliki. Sehingga umumnya komputer dalam bentuk PC di perpustakaan hanya 1 buah kecuali perpustakaan MTsN2 yang sudah berjumlah 3. Menurut pengelola perpustakaan Madrasah bahwa perabot perpustakaan mereka mendapatkan perhatian untuk ditambah saat akan dlakukan penilaian akreditasi madrasah atau perpustakaan. 


\section{d. Sistem layanan perpustakaan}

Sistem layanan perpustakaan madrasah umumnya sistem terbuka, 2perpustakaan madrasah memberikan layanan untuk koleksi referen secara tertutup dan 1 perpustakaan madrasah memberikan layanan semua koleksi secara tertutup disebabkan kondisi ruangan bercampur dengan unit kegiatan lain seperti pada perpustakaan MTs Muslimat NU, perpustakaan ini tidak mempunyai rak namun hanya mempunyai lemari untuk menyimpan koleksi bukunya.

1) Layanan Peminjaman

Kegiatan layanan peminjaman pada perpustakaan madrasah yang diteliti masih banyak menggunakan peminjaman secara manual hanya ada 1 madrasah yang sudah memberikan layanan secara komputer yaitu MA Muslimat NU. Kegiatan layanan peminjaman komputer ini dapat dilakukan jika semua atau sebagian besar koleksi dan anggota sudah terentri di aplikasi yang digunakan. Sedangkan pada madrasah yang sebenarnya sudah menggunakan aplikasi namun tidak memberikan layanan secara komputer adalah disebabkan belum terentrinya data koleksi buku di perpustakaan.

2) Layanan keanggotaan

Kebanyakan perpustakaan madrasah membuatkan kartu anggota perpustakaan untuk siswa, hanya 2 perpustakaan madrasah yang kartunya sudah dilengkapi dengan barkot sebagai sarana transaksi peminjaman dengan komputer. Namun hanya 1 madrasah yang sudah menerapkan untuk transaksi peminjaman. Sedangkan yang lainya masih belum menyiapkan dengan alasan sarana dan prasarana yang masih belum tersedia.

3) Layanan Teknologi Informasi

Layanan teknologi informasi ini masih banyak yang belum menerapkan disebabkan oleh sarana teknologi khususnya komputer yang masih kurang. Teerutama pada perpustakaan MI yang komputernya menggunakan laptop pribadi milik pengelola perpustakaan, sedangkan di MTsN dan 
MTs Muslimat NU masing-masing disediakan fasilitas komputer 1 buah bahkan ada yang lebih seperti di MTsN 2 yang sudah dapat menerapkan absen pengunjung dan katalog koleksi buku memakai komputer.

Perpustakaan madrasah yang menerapkan teknologi informasi dapat meningkatkan kwalitas dan kecepatan proses layanan informasi kepada pengguna perpaustakaan sehingga memperlancar proses belajar mengajar di madrasah. Peran teknologi informasi telah banyak digunakan di perpustakaan untuk mempermudah pengguna dalam mencari informasi yang dibutuhkan. Padahal hampir setiap madrasah punya sambungan internet yang seharusnya dapat dimanfaatkan dalam menunjang layanan pepustakaan yang berabasis teknologi informasi.

e. Program pemanfaatan perpustakaan oleh guru dan siswa

Hampir semua madrasah memberikan layanan peminjaman koleksi untuk siswa dan guru, kecuali madrasah yang tidak ada perpustakaannya. Sebagian besar madrasah yang memiliki perpustakaan mempunyai program kunjungan kunjungan ke perpustakaan. Perpustakaan madrasah menyediakan layanan yang memungkin untuk guru membawa siswanya untuk membaca di perpustakaan dan biasanya dijadwalkan. Sejumlah perpustakaan madrasah mebuat beberapa program yang tujuannya untuk meningkatkan pemanfaatan perpustakaan di madrasah. Berikut ini sejumlah inovasi yang dilakukan oleh perpustakaan madrasah dalam rangka meningkatkan kunjungan ke perpustakaan.

Bentuk kegiatan setiap perpustakaan madrasah umumnya sama dan perbedaannya hanya pada kreatifitas dan inovasi dari pengelola perpustakaan.

Berikut berbagai kegiatan yang perpustakaan madrasah di kota Palangka Raya lakukan dalam meningkatkan pemanfaatann perpustakaan.

1) Bekerjasama dengan guru mata pelajaran untuk membawa siswa ke perpustakaan dalam program membaca bersama siswa.

Kegiatan ini hampir semua madrasah melakukannya sebgai bagian dari pelaksanaan kurikulum.Namun program ini tidak selalu konsisten dilaksanakan selain itu koleksi buku yang dibaca tidak mengalami 
perkembangan dan tidak menarik serta menurut siswa tidak ada buku yang baru. Padahal untuk mengajak anak membaca ini lebih dahulu didasarkan pada minat. Jika tidak ada minat, maka kebiasaan embaca sudah pasti tidak akan berkembang. ${ }^{32}$ Tujuan perpustakaan dalam pengembangan koleksi yang menjadi utama adalah untuk menunjang kurikulum dan program-program madrasah, namun perpustakaan madrasah juga perlu untuk mengadakan koleksi yang bertujuan untuk meningkatkan minat baca siswa. Kegiatan membaca yang dilakukan bagi siswa diharapkan dapat meningkatkan pengetahuan dan keterampilan siswa dan gairah belajar siswa sehingga potensi anak semakin berkembang.

2) Gerakan membaca 15 menit setiap hari sebelum belajar atau saat istirahat. Kegiatan ini sebenarnya dimulai sejak tahun 2015 sebagai bagian dari program literasi untuk meningkatkan minat baca siswa di Madarasah. Namun gerakan ini tidak konsisten dilaksanakan oleh madrasah. Hanya ada 3 madrasah di koota Palangka Raya yang masih melaksanakan dengan pilihan waktu dan tempat yang berbeda, seperti MIN 1 di kelas sebelum belajar, MTs Muslimat NU dan MTsN 2 pada saat jam istirahat. Kegiatan ini merupakan pelaksanaan dari program pemerintah melalui kementerian pendidikan dan kebudayaan dalam menggerakkan minat baca siswa di sekolah dan bersifat wajib bagi setiap sekolah. Sebagaimana yang dituangkan dalam permendikbud nomor 23 tahun 2015 tentang penumbuhan budi pekerti. Sedangkan pada MTsN 2 mengimplementasikan program ini dengan gerakan 1 hari 1 buku atau gerakan one day one book (godok).

3) Menyebarkan koleksi buku ke setiap kelas untuk pengadaan sudut baca di setiap kelas dalam program literasi untuk siswa

Kegiatan ini sebagai pengembangan dan inovasi dari kegiatan membaca 15 menit sebelum belajar di atas. Siswa disediakan buku bacaan langsung

\footnotetext{
${ }^{32}$ Hari Santoso, Membangun minat baca anak usia dini melalui penyedian buku bergambar, Makalah, UPT Perpustakaan Universitas Negeri malang, 2008. Hal. 3

http://digilib.um.ac.id/images/stories/pustakawan/pdfhasan/Membangun\%20minat\%20 baca\%20anak\%20usia\%20dini\%20melalui\%20penyediaan\%20buku\%20bergambar.pdf. Diakses tanggal 24 September 2019.
} 
di kelas dan tanpa harus ke perpustakaan. Kegiatan ini dilakukan oleh MIN 1 Palangka Raya.

Kegiatan ini di satu sisi bagus untuk mendekatkan siswa dengan sumber bacaan, namun di sisi lain dapat mengurangi dari fungsi perpustakaan sebagai tempat penyimpanan dan pelayanan sumber informasi di madrasah. Siswa merasa tidak perlu lagi ke perpustakaan karena di setiap kelas sudah disediakan koleksi bacaan yang paling deakat untuk diakses. Namun ada juga yang beranggapan bahwa kegiatan ini bukan bagian dari mengurangi fungsi perpustakaan sebagai sumber belajar, namun justru sebagai bagian dari mendekatkan perpustakaan ke pada para peserta didik di madrasah. Kegiatan ini juga bagus dilakukan bagi madrasah yang memiliki ruangan perpustakaan sendiri. Manfaat lain dari sudut baca di kelas ini adalah terakait dengan kurangnya waktu yang dimiliki siswa di madrasah untuk membaca dapat diatasi, sebab bagi siswa untuk mengkses informasi buku bacaan tidak butuh waktu lama.

4) Menyediakan lemari display koleksi buku di luar kelas agar siswa tertarik untuk membaca koleksi perpustakaan

Kegiatan ini adalah dengan meletakkan rak display yang terbuat dari kaca dan dilengkapi dengan buku absen. Koleksi yang didisplay ditampilkan secara bergilir dari beberapa koleksi yang dimiliki perpustakaan khusunys jenis koleksi buku pengayaan baik fiksi maupun non fiksi. Metode seperti ini sebagai inovasi untuk memberikan aalternatif tempat membaca bagi siswa yang selama ini kegiatan membacanya di dalam ruangan. Siswa dapat membaca sambil melihat aktifitas teman-temannya di halaman, tidak terikat dengan aturan membaca di dalam ruangan serta manfaatnya bagi perpustakaan adalah koleksi dapat ditingkatkan pemanfaatnnya oleh siswa. Inovasi seperti ini dilakukan oleh perpustakaan MTs Muslimat NU Palangka Raya.

5) Memberikan penghargaan kepada siswa yang paling rajin ke perpustakaan Pemberian penghargaan ini sebagai bagian dari meningkatkan pemanfaatan perpustakaan madrasah oleh siswa dan meningkatkan minat 
baca peserta didik di madrasah. Penghargaan yang diberikan umumnya adalah dalam bentuk buku bacaan dan perlengkapan sekolah siswa. Penghargaan diaberikan langsung oleh kepala madrasah. Kegiatan ini dilakukan oleh perpustakaan MTsN 2, MI Muslimat NU.

6) Program membawa siswa berkunjung ke perpustakaan lain yang dikoordinir oleh perpustakaan madrasah

Program ini dilaksanakan oleh perpustakaan MTsN2 melalui berbagai program yang dibuat oleh perpustakaan dan didukung oleh kepala madrasah. Ada beberapa tempat yang mereka kunjungi seperti perpustakaan daerah provinsi Kalimantan Tengah, Balai Bahasa Kalimantan Tengah dan juga ke UPT Perpustakaan IAIN Palangka Raya. Kunjungan ini dimaksudkan untuk mengenalkan siswa dengan berbagai pusat informasi dan perpustakaan lain, baik dari aspek jenis koleksi yang dimiliki, sistem layanan yang digunakan dan memahami bagaimana fungsi perpustakaan sebagai sumber informasi yang bermanfaat sebagai sarana belajar seumur hidup. Kegiatan ini juga sebagai sarana sosialisasi MTsN 2 terkait beberapa gerakan atau program yang mereka lakukan untuk peningkatan kemampuan literasi siswa seperti "Pakalis" (Pembentukan Karakter dan Kemampuan Literasi Sekolah) atau "Godok" (Gerakan One Day One Book). Gerakan godok ini dilakukan dengan memberikan hadiah kepada siswa yang rajin meminjam buku di perpustakaan.

\section{Kesimpulan}

Sebagai penutup dapat disimpulkan bahwa :

1. Perpustakaan madrasah di kota palangka raya tidak mempunyai rencana strategis maupun grand desain serta program yang jelas dan terukur dalam pengembangan perpustakaan.

2. Perpustakaan madrasah di kota Palangka Raya belum mempunyai program yang jelas dalam pengembangan tenaga pengelola perpustakaan yang professional sehingga masih banyak madrasah yang belum memiliki tenaga berlatar belakang pendidikan perpustakaan. 
3. Kegiatan pengembangan koleksi di perpustakaan madrasah kota Palangka Raya hanya rutin pada buku mata pelajaran yang bersumber dari dana BOS, sedangkan pengembangan koleksi pada jenis koleksi buku pengayaan anggarannya sangat sedikit dari komite dan bahkan sebagian tidak ada dianggarakan. Sistem pengadaan koleksi buku di Madrasah bersifat terpusat serta tidak banyak melibatkan pengelola perpustakaan. Selain itu dalam pengelolaan koleksi juga masih belum standard an sebagian besar masih manual, sehingga informasi komprehensif terkait koleksi yang mereka miliki tidak bisa ditampilkan atau diinformasikan kepada pengguna perpustakaan.

4. Sarana prasarana perpustakaan Madrasah Kota Palangka Raya masih banyak yang belum standar dan sangat lambat peningkatannya, disebabkan oleh anggaran yang sedikit. Selain itu masih ada madrasah yang menganggap perpustakaan belum penting sehingga sementara waktu diganti dengan ruangan lain atau disatukan dengan ruangan lainnya.

5. Sistem layanan perpustakaan madrasah semua bersifat terbuka dan kebanyakan bersifat manual atau belum menerapkan aplikasi.

6. Kegiatan inovasi madrasah dalam pemanfaatan perpustakaan oleh siswa dan guru adalah bekerjasama dengan guru untuk membawa siswa ke perpustakaan dalam kegiatan membaca bersama dan menyimpulkan buku bacaan yang dibaca; menggunakan perpustakaan untuk sarana pemutaran film yang bersifat edukasi, memberikan penghargaan kepada siswa yang paling rajin ke perpustakaan; menyebarkan koleksi buku ke setiap kelas untuk pengadaan sudut baca di setiap kelas dalam program literasi untuk siswa; menyediakan lemari display koleksi buku di luar kelas agar siswa tertarik untuk membaca koleksi perpustakaan; perpustakaan ikut serta menjadi fasilitator lomba bagi siswa setiap akhir semester; membuat gerakan one day one book (godok); membawa siswa berkunjung ke perpustakaan lain di kota Palangka Raya. 


\section{Daftar Pustaka}

Andi Praswoto; Manajemen Perpustakaan Sekolah Profesional, Diva Press, 2012

Dian Sinaga, Mengelola Perpustakaan Sekolah, (Jakarta: Kreasi Media Utama, 2007)

Darmono, Manajemen dan Tata Kerja Perpustakaan Sekolah, Jakarata: Grasindo, 2001

Evans, G.E.,\& Carter, T.L. (2009). Introduction to library public services ( $7^{\text {th }}$ ed.). Westport, Conn.: Libraries Unlimited.

Hari Santoso, Membangun minat baca anak usia dini melalui penyedian buku bergambar, Makalah, UPT Perpustakaan Universitas Negeri malang, 2008.

Mbulu, Joseph. Pemanfaatan Perpustakaan Sekolah Dalam Kegiatan Belajar Mengajar. Majalah Pendidikan, XIX. (1992).

Peraturan Menteri Pendidikan Nasional Nomor 25 Tahun 2008 tentang standar Tenaga Perpustakaan Sekolah/Madrasah

Peraturan Menteri Pendidikan Nasional Nomor 24 Tahun 2007 tentang standar sarana dan prasarana untuk sekolah dasar/madrasah ibtidaiyah (SD/ MI), Sekolah Menengah Pertama/Madrasah Tsaniwiyah (SMP/MTs), dan Sekolah Menengah Atas/Madrasah Aliyah (SM/MA).

PP nomor 24 Tahun 2014 tentang Perpustakaan

Qalyubi, Syihabuddin dkk. 2007. Dasar-Dasar Ilmu Perpustakaan dan Informasi. Yogyakarta: Jurusan Ilmu Perpustakaan dan Informasi (IPI) Fakultas Adab UIN Sunan Kalijaga.

Sardiman A.M.; Interaksi dan Motivasi Belajar Mengajar, Jakarta; Rajawali Pers, 2012

Sumantri, MT. Panduan Penyelenggaraan Perpustakaan Sekolah. Bandung: PT Remaja Rosdakarya, 2008

Syaiful Sagala, Konsep dan makna pembelajaran: untuk membantu memecahkan problematika belajar dan mengajar, Bandung: Alfabeta, 2017. 
Undang-Undang Nomor 20 Tahun 2003 tentang Sistem Pendidikan Nasional Undang-undang RI No. 43 Tahun 2017 tentang Perpustakaan

Yati Afianti, Focus Group Discussion (diskusi kelompok terfokus) sebagai metode pengumpulan data penelitian kualitatif, Jurnal Keperawatan Indonesia, Volume 12, No. 1, Maret 2008;

Yusuf, Pawit M. dan Suhendar,Yaya.Pedoman Penyelenggaraan Perpustakaan Sekolah. Jakarta: Kencana, 2005.

Wolfe, J.,Naylor, T., \& Drueke, J. (2010). The Role of the Academic Reference Librarian in the Learning Commons. Reference \& User Services Quarterly, 50(2), 108-113

http://digilib.um.ac.id/images/stories/pustakawan/pdfhasan/Membangun\%20minat\%20baca\%20anak\%20usia\%20dini\%20melalui\%20 penyediaan\%20buku\%20bergambar.pdf. Diakses tanggal 24 September 2019. 